\title{
THE IMPORTANCE OF APPLIANCE COIN \& FUND IN TEACHING
}

\section{Lidija Barjaktarović1, *, Biljana Lazarević ${ }^{2}$ Veljko Davidović}

\author{
${ }^{1}$ Singidunum University, \\ Belgrade, Serbia \\ ${ }^{2}$ Casa Forte d.0.0., \\ Belgrade, Serbia
}

\begin{abstract}
:
The subject of the article is presentation and the emphasis on the importance of appliance of educational business simulation Coin \& Fund in teaching process. The aim of the article is to stress which important lessons students get by usage of Coin \& Fund during the Bachelor degree studies in the field of applied economics.

Coin \& Fund is developed in Republic of Serbia as result of partnership cooperation between Singidunum University and Casa Forte Belgrade. Coin \& Fund is designed and implemented as educational tool which helps different users (students) to understand how their decisions, as managers of virtual companies, have impact on overall company's business through basic financial reports, i.e., chosen profitability ratios.
\end{abstract}

Keywords:

Educational simulator, Coin \& Fund, decisions, ratio numbers, risks.

\section{INTRODUCTION}

According to Shannon simulation is "the process of designing model of real system and execution of experiments together with it in order to understand system's behaviour or evolution of different strategies (within determined boundaries or within defined criteria)". [1]. Furthermore, it can be said that business simulation represents activities which describe real states from the outside worlds, but in protected and controlled environment, in order to become familiar with particular business process and final results. [1,2]

Establishment and appliance of simulations allow students, researches and business people deeper and more complete insight in business processes and adequate tool for qualitative analysis. [3,4] Learning based on simulations is especially effective in developing decision making skills. During usage of simulation students get specific knowledge for defined discipline which they can implement further in professional environment. Moreover, simulations help students to learn more than defined discipline required, because it involves organization and interaction with other discipline, people and entities. Finally, simulations have special value in integrating different teaching goals, through connecting various principles or general knowledge with practical skills. This

\section{Lidija Barjaktarovic}

e-mail:

lbarjaktarovic@singidunum.ac.rs 
comprehensiveness of simulation makes it as very powerful pedagogical tool for integrated or final courses. $[3,4,5]$

The subject of the article is presentation and the emphasis on the importance of appliance of educational business simulation Coin \& Fund in teaching process. The article is intended to all individuals who are keen on further professional development. The aim of the article is to stress which important lessons students get by usage of Coin \& Fund during the Bachelor degree studies in the field of applied economics.

On regional market are present following simulators: Holcim's Ecoism (Economic Business Simulator), Mercuri International (Sweden Investment Company), H.art Development centre (consultant in human resources management, leadership, training, etc.) SimTeam Online Business simulation /outsource/ and EDUardo On-line Business simulation for individual work /outsource/, Rockwell Automation's Arena Basic, Palisade's @Risk, „Virtuelna burza“ Academia of Zagreb Stock Exchange, etc. [6, 7, 8, 9, 10, 11, 12, 13]

Coin \& Fund is different from other educational business simulators because: 1 ) it is developed in Republic of Serbia, as result of partnership Singidunum University and Casa Forte Belgrade; 2) it is applied in teaching process from the first until the end of fourth year of academic bachelor degree studies on the Faculty of Business in Belgrade; it is applied on exercise classes of different professional courses in accordance with accredited curriculum; it allows students to have continuous progress in acquiring new knowledge and skills, i.e. they are trained to make appropriate business decisions. 3) Students are actively involved in every phase of educational simulation development. 4) Simulation results/outcomes depend on concrete choice of decision maker/s (other simulation solutions are based on predefined options). 5) Simulation represents functioning of the market, because demand and supply of Coin \& Fund are determined by decisions of other players - virtual companies which are at the same time in the game (i.e. quantities of goods are limited). 6) In the practice companies of all size can use Coin \& Fund; especially it is convenient for entrepreneurs (competitive simulations are aimed to employees in big companies and banks). It is important to emphasize that Coin \& Fund can be used for solving of particular problems of any company, because starting point for any entity is the official or periodical financial reports. Representatives of Casa Forte wished to implement their experience in practice on improvement of business processes in companies related to the development of educational business simulator Coin \& Fund. They noticed that within: 1) small and medium sized companies, that decision makers are not aware of influence of their decisions on business result, 2) bigger companies that team members don't show interest for activities of other organizational parts in order to achieve better result of organizational part where they work in. On the other hand, representatives of academic community: 1) had opportunity to improve their knowledge related to different international business schools, where educative simulators are integral part of teaching process, and they were very interested to implement own academic and practical knowledge in development of Coin \& Fund. 2) They are committed to develop skilfully employees and entrepreneur from student days.

Coin \& Fund is developed in Republic of Serbia as result of partnership cooperation between Singidunum University and Casa Forte Belgrade. Coin \& Fund is designed and implemented as educational tool which helps different users (students) to understand how their decisions, as managers of virtual companies, have impact on total company's business through basic financial reports, i.e., chosen profitability ratios. Students have on disposal heritage in the amount of EUR 100,000 in cash, which they have to manage in the following period. Cash can be used for the trade with commodities or securities or foreign-exchange, i.e. depositing with banks or applying for the appropriate loan.

In addition to Introduction and Conclusion, the work is structured as follows. In the first chapter general characteristics of Coin \& Fund will be presented. In the second chapter, simulation of the program Coin \& Fund will be presented. In the third chapter focus will be on company's management of ratio numbers. In the fourth chapter will be identified business risks with which students will be met. In the fifth and sixth chapter students' activities, impressions and learned lessons by applying Coin \& Fund will be presented.

\section{GENERAL CHARACTERISTICS OF EDUCATIVE BUSINESS SIMULATOR COIN \& FUND}

Coin \& Fund is a client-server application intended to be accessed via internet browser /such as Internet Explorer or Google Chrome/ as to achieve flexibility and impose determined configuration standards. The server is in a remote location or cloud, and working in operating system Linux. Server-side application is implemented in accordance with the requirement of Coin \& Fund. 
Additional functionalities of the application are:

- Auto save - allows storage of previous simulation's results (all movements and accompanied financial reports), and possibility to stop and continue usage of application in any moment.

- Delivery of financial documents (balance sheet, invoice, etc.) in accordance with defined law frame.

- Administrator console through which there is an insight into the business of all enterprises, statistics, simulation results, etc.

- Overall security of Coin \& Fund against cyberattacks.

\section{THE COURSE OF THE EDUCATIONAL BUSINESS SIMULATION COIN \& FUND}

When all users (students) choose and configure their virtual company, the simulation starts. Everyone has the opportunity to make its decisions without consulting with colleagues (or teammates) or negotiating with its associates on the optimal solution for each problem.

To make the game adaptable to different situations, two different time flows in the simulation were implemented:

- Real-time runs at real speed, that is, the current simulation time is the same as in the real world.

- Accelerated - the program simulates a certain amount of time at the end of the move.

This quantity can be manually selected before the simulation starts. In this way, the game will take the same length in real time, while the simulated time will be able to vary in order to adapt to the situation.

Performance indicators (ratios numbers) are visible on the screen, with the possibility that the user has a detailed insight at any time and monitors their dynamics (for example, using graphics) by comparing the initial state with the indicators obtained after the decision.

Decisions that every user can bring to their company are a key part of the simulation, and are related to:

- Financial assets - term deposits with the bank, use of bank loans in the amount corresponding to the creditworthiness of the company, conversion of funds into different foreign currencies and sale of shares on the Belgrade Stock Exchange.

- Physical assets - buying and selling up to three different types of goods and sales through a warehouse (leased or owned).
Customer (student) can be connected with server on the basis of entering appropriate internet address and following instructions on the screen.

Coin \& Fund consists of 5 modules. These are: financial reports, stock exchange, exchange office, bank and trade. In each module, student can see the company's financial standing through profitability (ROE - Return on Equity, ROA - Return on Assets, EBIT - Earnings before Interest and Taxes) and Altman Z-score model (reveals the risks of running a company's bankruptcy).

The Financial statements module includes balance sheet, income statement and statement of cash flows. The result of the implemented business decisions is recorded directly through the appropriate financial report.

The Stock exchange module is directly linked to the Belgrade Stock Exchange (BELEX) website, and enables the purchase and sale of shares at real prices.

The Exchange office module allows student to trade in selected foreign currencies. The currency exchange rate corresponds to the real values on the domestic financial market.

Module Bank enables short-term deposit or lending of funds, at fixed or variable interest rates, in selected convertible currencies. The basic interest rate on the loan is calculated using the Altman Z-score model, taking into account the value of the loan requested. When considering the borrowing option, a student may, for the purpose of making a decision, receive a Bank Credit Offer. In the case of deposit money, it is necessary for a student to enter into the simulation the appropriate combination of currency, term and chosen commercial bank, in order to receive a proper banks' offer. The interest rates are realistic and correspond to the offers of all banks operating in the Republic of Serbia.

The Trade module includes certain types of goods, which must be kept in the warehouse of adequate capacity and with the appropriate number of employees employed. Thus, the decisions that precede the trade in goods are related to the purchase or lease of the warehouse space, and depending on the size of the capability, the engagement of the appropriate number of employees, which can be either full-time employed or outsourced. Prices, discounts and terms of payment depend on the type and quantity of goods. Also, in the case of sales, stocks can be sold in the country or abroad, with the desired margin, rebate and discount on quantity. 


\section{THE MANAGEMENT OF VIRTUAL ENTERPRISES' RESOURCES HAS BEEN DRIVEN BY NUMBER RATIOS}

Ratio numbers show key performance of the company. Ratio numbers are used primarily to assess the company's ability to service debt obligations, primarily to creditors, i.e. banks. Ratio analysis is also a practical means of control in the process of managing the company's financial system. [14,15] Important lessons for students are that ratio numbers have their practical value only if they are properly interpreted, and that external stakeholders consider the business of the company through the financial performance of the company.

Profitability ratios indicate the earning capacity of an enterprise. The main goal of the company's business, in our terms, is to maximize profit [15]. Thus, this group of indicators (ROA, ROE, and EBIT) is given a primacy.

Altman's synthetic indicator of financial uncertainty known as the ZETA analysis model or Z - score model is a synthetic indicator of financial uncertainty. It reveals the risks of bankruptcy occurrence of the company, by means of accounts indicating solvency, liquidity, profitability and efficiency. [14,15]

Its basic purpose is to evaluate the company's credit risk as applicant with commercial bank. A score obtained in the form of a single digit indicates the degree of risk for the bank when granting a loan to the particular company. Banks have pre-formulated upper and lower creditworthiness thresholds of the company. If the $\mathrm{Z}$ score is above the upper threshold, the credit risk is acceptable for the bank. If this figure is below the lower threshold, credit risk is unacceptable for the bank. If the $\mathrm{Z}$ - Score is between the upper and lower thresholds, banks need to evaluate on the basis of additional documentation and experience whether they can accept such a credit risk. [14] An important lesson for students is that the loan price is not the same for all credit beneficiaries, and that bank's accepted risk is directly reflected in the interest rate.

\section{RISKS WHICH STUDENTS CONSIDER WHEN USING COIN \& FUND}

Business risk is certainly the first [4], considering the fact that the decisions in which funds will be invested, will affect achieved earnings. There is always a dilemma whether to invest in transactions that are known, or should accept the unknown and go further.
Financial risks are a special sub-category of business risk [4]. Students face the full range of financial risks, starting from market (especially foreign exchange, interest rate, price and competition), through credit and exposure risk, to liquidity risk and capital management.

Market risks [16] are present in each area of decision making in an educational business simulation, whether and when students are traded in goods, securities or foreign exchange, or which payment instruments are the most acceptable for execution of a specific business transaction. The risk of competition [16] is observed in the quantity of present goods in the market, which depends on the number of (virtual) companies at the moment of using the educational business simulation of Coin \& Fund.

Credit risk [16] appears at the moment when a decision is made to grant a deferred payment to a particular buyer. This further exposes the examination of exposure to one entity on the basis of all non-collected receivables.

Capital is the basic determinant for risk management in an enterprise's business, and the essence is that it grows over time, that is, profit grows from year to year [16]. As stated, the initial amount of capital is EUR 100,000 and should be increased by making decisions that will ensure optimum profitability indicators.

Finally, the liquidity risk [16] is present at every moment of decision-making. It is not enough just to settle the obligation on time, but also in full amount.

\section{ACTIVE PARTICIPATION OF STUDENTS IN ALL COIN \& FUND PHASES OF DEVELOPMENT AND TESTING}

Having in mind that this tool has been developing in stages, it is prescribed that students have been involved in testing and give suggestions for further improvement of simulator.

Students had a lot of constructive suggestions for further tool development. For example: define the selection options, so that instead of numbers, the letters will be written. The proposal was to introduce option of cancellation of renting or selling a warehouse at any time. Then, the suggestion was to allow the free movement of sales prices of goods in stock. Also, the proposal was that the precise prediction was made from what moment the purchase of goods from the supplier could go to the deferred payment. It is interesting that the tests of educational business simulations resulted in the development of an appropriate user guide for all interested Coin \& Fund users. 
Student impressions at all stages of development and testing of Coin \& Fund have been very positive. Special attention is given to the holistic approach to the perception of virtual business operations and the team work of colleagues in the group.

\section{WHAT ARE STUDENTS INTEND TO LEARN BY MAKING DECISIONS IN THE BUSINESS OF VIRTUAL ENTERPRISE?}

The results of implemented decisions help students in perceiving which courses could help them gaining additional knowledge, no matter what field they belong to financial markets, risk management, banking, trade or business finance.

The logic of applying the appropriate exchange rate for the purchase or sale of foreign currency is the first challenge they face. Then, trading in shares represents an unknown if the logic of the securities itself and the corresponding financial market is not understood. The present dilemma is whether to own or rent a warehouse space. Furthermore, the interpretation of ratios numbers is very important for all business ventures. What are all relevant elements to placing or borrowing money from the bank? ... Etc.

It is also important to learn to communicate with colleagues from other study programs, or to precisely define their requirements. In the Coin \& Fund testing, there are students from two different study programs business economics and information technology (IT). The result of successful communication is that IT students understood the financial logic, especially in the following areas: 1) companies have receivables from the customers, and obligations toward suppliers; 2 ) when selling foreign currency to a commercial bank, the purchase (lower) price is used, and that when buying a foreign currency, the commercial bank applies the selling (higher) rate.

Finally, we can conclude that Coin \& Fund enables teaching students about correct and analytical perception of business decisions, making them better colleagues, employees and entrepreneurs because it simulates the business of the entire company. The educational business simulation of Coin \& Fund helps students combine theoretical and practical knowledge. Furthermore, usage of Coin \& Fund is preparing them to get job more easily tomorrow or start their own business. Finally, appliance of Coin \& Fund helps students to gain soft skills such as teamwork and peer education.

\section{CONCLUSION}

The educational business simulation Coin \& Fund is aimed at helping students to combine theoretical and practical knowledge. It can be concluded that Coin \& Fund can teach students about the correct and analytical perception of business decisions, making them better for colleagues, employees and entrepreneurs because it simulates the business of the entire company. Furthermore, it has a capacity to prepare them to get job more easily tomorrow or start their own business. Finally, it can help them to gain the skills of teamwork and peer education.

It is important that students understand from which courses they should get additional knowledge, whether they are financial markets, risk management, banking, trade, business finance, or the development of the socalled soft skills, such as communication, teamwork, peer education, and so on.

The future research will focus on monitoring student results from the moment of enrolment at the Faculty of Business in Belgrade until the graduation of a graduate economist, in order to determine how successful they were in getting and applying knowledge in usage of Coin \& Fund.

\section{ACKNOWLEDGMENT}

This research paper was the part of the project "Advancing Serbia's Competitiveness in the Process of EU Accession", no. 47028, in the period 2011-2018, financed by the Serbian Ministry of Science and Technological Development.

\section{REFERENCES}

[1] V. Dušak, "Simulacijsko modeliranje u procesu odlučivanja", Zbornik radova 16, Fakultet organizacije i informatike, Varaždin, p. 65-71, 1992.

[2] G.Knežević, N.Stanišić, and V.Mizdraković, Analiza finansijskih izveštaja namenjena tržištu Republike Srbije. Beograd: Univerzitet Singidunum, 2017.

[3] Ž. Milovanović, M.Stojanović, and D.Regodić, "Simulacija poslovnog procesa u turizmu primenom SIMPROCESS softvera", Zbornik radova Sinergija University Scientific Conference, p. 56-60, 2016

[4] L. Barjaktarović, Upravljanje rizikom. Beograd: Univerzitet Singidunum, 2015. 
[5] L. Barjaktarović, Z.Jović, and M.Milojević, Poslovne finansije. Beograd: Univerzitet Singidunum, 2018.

[6] Rockwell Automation Inc. USA (2010) Arena Basic, Users' Guide

[7] R.Shannon, "Systems simulation - the Artand Science”, Englewood Cliffs, Prentice-Hall, New York. 1975.

[8] S.Milovanović, I.Pantelić, and I.Damnjanović, "Povećanje kvaliteta kroz integrisanu upotrebu simulatora", Zbornik 53. Konferencije ETRAN, Zlatibor, str. 2.7.1-4 VI, 03-06/06/2013.

[9] T.Kaurin, N.Bulatović, and D.Anucojić, "Modeliranje i simulacije kao sistemi podrške u odlučivanju“, INFO TECH 2011 ICT Conference \& Exhibition, Vrnjačka Banja, 2011.
[10] Web site Eduardo, https://edu-simulation.com/, date of access $02 / 11 / 19$

[11] Web site Mercuri International, https://mercuri.rs/ poslovne-simulacije-slider/, date of access 02/11/19

[12] Web site Palisade, https://www.palisade.com/risk/ default.asp, date of access 02/11/19

[13] Web site SimTeam, https://simteamtraining.com, date of access 02/11/19

[14] Web site H.art Development Center, http://hart.rs/ sr/ostale-usluge, date of access 02/11/19

[15] Web site Holcim, https: www.holcim.co.nz/careers/ working-at-holcim/supporting-your-development, date of access 02/11/19

[16] Web site Akademija Zagrebačke burze, https:// www.akademijazse.hr/, date of access 02/11/19 